\title{
ANALISIS PENGARUH PENERAPAN SISTEM PENGENDALIAN INTERNAL TERHADAP SISTEM AKUNTANSI PENGGAJIAN DAN PENGUPAHAN
}

\author{
Hadi Samanto \\ Institut Teknologi Bisnis AAS Indonesia \\ Email: hadisamanto6110@gmail.com
}

\begin{abstract}
Internal control is necessary to determine the correct amount of salary and wages paid to the laborer and is guaranteed that the salary and wages paid to the workers who are entitled to receive it, in addition to preventing the payment of salaries and wages to fictitious workers or the amount of salary paid is too large or incorrect. The purpose of this research is to partially and partially determine the role of organizational structure, authority system and recording procedures, and healthy practices affect payroll and wage accounting systems. The population in this study is the entire workforce PT Ardian Mulia Perkasa with a total of 39 people (based on the number of workers in early 2021), so the number of samples in this study is also as many as 39 people. The sampling method in this study used a saturated sample technique in which the entire population was used for the sample. The role of elements of organizational structure, system of authority and recording procedures, as well as healthy practices simultaneously affect the payroll accounting system and wages. This is evidenced by the results of the study that the value of significance is smaller than the level of 5\% $(0.000<0.05)$ and the value of $F$ hitung is greater than the value of Ftabel (22,446 > 2.87) and the contribution of influence to the payroll accounting system and wages of $62.9 \%$ while the remaining $27.1 \%$ is influenced by other factors that are not studied. Researchers are very grateful to the company and the parties who provide the data and time to be completed on time.
\end{abstract}

Keywords: internal control system, payroll system, wages.

DOI: http://dx.doi.org/10.29040/jap.v20i1.2471

\section{PENDAHULUAN}

Pembayaran gaji dan upah merupakan aktivitas rutin dilakukan oleh perusahaan. Hal ini dirancang untuk memberikan hak kepada tenaga kerja yang ada telah memberikan energi dan ide untuk perkembangan perusahaan. Sehingga sangat diperlukan sistem yang dapat mengontrol gaji dan upah perusahaan. Sistem yang dimaksud adalah sistem akuntansi penggajian dan pengupahan yang dapat mengontrol gaji dan upah tenaga kerja. Sistem ini juga dapat digunakan sebagai alat bantu mendeteksi penyimpangan yang terjadi di dalam perusahaan. Sistem akuntansi selalu saja digunakan oleh manajemen untuk menganalisis dan mengevaluasi semua hal yang terkait dengan pembiayaan perusahaan. Salah satunya yang berkenaan dengan penggajian dan pengupahan tenaga kerja. Pimpinan sebuah perusahaan tidak mungkin mengendalikan secara menyeluruh terhadap biaya tenaga kerja. Oleh karena itu diperlukan suatu pengendalian internal yang memadai terhadap gaji dan upah.

Menurut Mulyadi (2016) pengendalian internal adalah meliputi struktur organisasi, sistem otorisasi dan prosedur pencatatan, praktik yang sehat, serta karyawan yang mutunya sesuai dengan tanggungjawabnya. Manfaat sistem pengendalian internal bagi perusahaan dapat melindungi asset perusahaan dari pencurian, 
kecurangan, penyalahgunaan atau kesalahan penempatan. Untuk mendapatkan suatu sistem akuntansi yang baik diperlukan penerapan sistem pengendalian internal yang memadai pada perusahaan. Karena sistem akuntansi itu merupakan keseluruhan prosedur dan teknik yang diperlukan untuk mengumpulkan data dan mengolahnya sehingga menjadi informasi yang diperlukan sebagai alat bantu pimpinan perusahaan dalam melaksanakan pengawasan kerja.

\section{METODE PENELITIAN}

Populasi dalam penelitian ini adalah seluruh tenaga kerja PT. Ardian Mulia Perkasa dengan jumlah 39 orang (berdasarkan jumlah tenaga kerja awal tahun 2021), sehingga jumlah sampel dalam penelitian ini juga sebanyak 39 orang. Metode pengambilan sampel dalam penelitian ini dengan menggunakan teknik sampel jenuh dimana seluruh jumlah populasi digunakan untuk sampel. Variabel independen pada penelitian ini adalah struktur organisasi (X1), sistem wewenang dan prosedur pencatatan (X2) , praktik yang sehat (X3) sedangkan variable dependen penelitian ini adalah system akuntansi penggajian dan pengupahan. Pada penelitian ini analisis regresi digunakan untuk mengetahui sejauh mana hubungan variabel bebas (sistem pengendalian intern) terhadap variabel terikatnya (sistem akuntansi penggajian dan pengupahan). Persamaan regresi linear bergandanya adalah : $\mathrm{Y}=\mathrm{a}+\mathrm{b} 1 \mathrm{x} 1+\mathrm{b} 2 \mathrm{x} 2+\mathrm{b} 3 \mathrm{x} 3+\mathrm{e}$

\section{HASIL DAN PEMBAHASAN}

\subsection{Pengujian Instrumen}

Ketepatan data dalam pengujian suatu hipotesis tentang hubungan antara variabel sangat tergantung pada kualitas data yang dipakai dalam pengujian tersebut. Pengujian hipotesis tidak akan tepat sasaran, apabila data yang dipakai tidak valid dan tidak reliabel. Pada penelitian ini, data yang diperoleh dari hasil penyebaran kuesioner pada 39 responden diolah menggunakan program SPSS 22 sehingga diharapkan menghasilkan kuesioner yang valid dan reliabel.

1) Uji Validitas

Uji validitas data dalam penelitian ini dilakukan dengan menggunakan uji person product moment. Hasil uji validitas dapat dilihat pada tabel berikut ini:

Tabel 1. Hasil Uji Validitas

\begin{tabular}{|c|c|c|c|}
\hline $\begin{array}{c}\text { Item } \\
\text { Pernyataan }\end{array}$ & $\begin{array}{l}\text { Item Total } \\
\text { Correlation }\end{array}$ & r Tabel & Keterangan \\
\hline \multicolumn{4}{|c|}{ Struktur Organisasi (X1) } \\
\hline A1 & 0,765 & 0,316 & Valid \\
\hline $\mathrm{A} 2$ & 0,868 & 0,316 & Valid \\
\hline A3 & 0,840 & 0,316 & Valid \\
\hline A4 & 0,862 & 0,316 & Valid \\
\hline A5 & 0,702 & 0,316 & Valid \\
\hline \multicolumn{4}{|c|}{ Sistem Wewenang dan Prosedur Pencatatan (X2) } \\
\hline B1 & 0,854 & 0,316 & Valid \\
\hline $\mathrm{B} 2$ & 0,926 & 0,316 & Valid \\
\hline B3 & 0,958 & 0,316 & Valid \\
\hline B4 & 0,899 & 0,316 & Valid \\
\hline \multicolumn{4}{|c|}{ Praktik yang Sehat (X3) } \\
\hline $\mathrm{C} 1$ & 0,604 & 0,316 & Valid \\
\hline $\mathrm{C} 2$ & 0,759 & 0,316 & Valid \\
\hline
\end{tabular}




\begin{tabular}{|c|c|c|c|}
\hline \multicolumn{5}{|c|}{ Jurnal Akuntansi dan Pajak, 22(01), 2021, 3 } \\
C3 & 0,726 & 0,316 & Valid \\
\hline C4 & 0,766 & 0,316 & Valid \\
\hline C5 & 0,709 & 0,316 & Valid \\
\hline \multicolumn{4}{|c|}{ Sistem Akuntansi Penggajian dan Pengupahan (Y) } \\
\hline D1 & 0,879 & 0,316 & Valid \\
\hline D2 & 0,909 & 0,316 & Valid \\
\hline D3 & 0,860 & 0,316 & Valid \\
\hline D4 & 0,887 & 0,316 & Valid \\
\hline D5 & 0,886 & 0,316 & Valid \\
\hline
\end{tabular}

Berdasarkan tabel diatas seluruh pernyataan dinyatakan valid karena hasil dari koefisien korelasinya lebih besar dibandingkan dengan nilai taraf signifikannya. Hal ini ditunjukan dengan semua pernyataan diatas mempunyai korelasi koefisien diatas nilai taraf signifikasi $5 \%$ yaitu diatas 0,316 sehingga semua pernyataan kuesioner penelitian tersebut dinyatakan valid untuk dilanjutkan penelitian yang lebih mendalam. Uji validitas ini juga dilakukan dengan nilai sig. (2-tailed) dengan probabilitas 0,05. Berdasarkan $r$ tabel pada lampiran seluruh pernyataan dinyatakan valid karena nilai sig. (2-tailed) dari koefisien korelasi lebih kecil dari probabilitas 0,05 sehingga kuesioner penelitian tersebut dapat dilanjutkan untuk penelitian yang lebih mendalam.

2) Uji Reliabilitas

Pengujian reliabilitas digunakan untuk mengetahui konsistensi hasil tentang tanggapan responden atas kuesioner yang disajikan. Hasil uji reliabilitas dapat dilihat pada tabel berikut ini:

Tabel 2. Hasil Uji Reliabilitas

\begin{tabular}{|c|c|c|c|}
\hline $\begin{array}{c}\text { Item } \\
\text { Pernyataan }\end{array}$ & $\begin{array}{c}\text { Cronbach's } \\
\text { Alpha }\end{array}$ & Keterangan \\
\hline \multicolumn{4}{|c|}{ Struktur Organisasi $\left(\mathbf{X}_{\mathbf{1}}\right)$} \\
\hline A1 & 0,849 & 0,60 & Reliabel \\
\hline A2 & 0,811 & 0,60 & Reliabel \\
\hline A3 & 0,822 & 0,60 & Reliabel \\
\hline A4 & 0,814 & 0,60 & Reliabel \\
\hline A5 & 0,879 & 0,60 & Reliabel \\
\hline Sistem Wewenang dan Prosedur Pencatatan $\left(\mathbf{X}_{\mathbf{2}}\right)$ & Reliabel \\
\hline B1 & 0,929 & 0,60 & Reliabel \\
\hline B2 & 0,906 & 0,60 & Reliabel \\
\hline B3 & 0,876 & 0,60 & Reliabel \\
\hline B4 & 0,909 & 0,60 & Reliabel \\
\hline C1 & \multicolumn{2}{|c|}{ Praktik yang Sehat $\left(\mathbf{X}_{3}\right)$} \\
\hline C2 & 0,782 & Reliabel \\
\hline
\end{tabular}




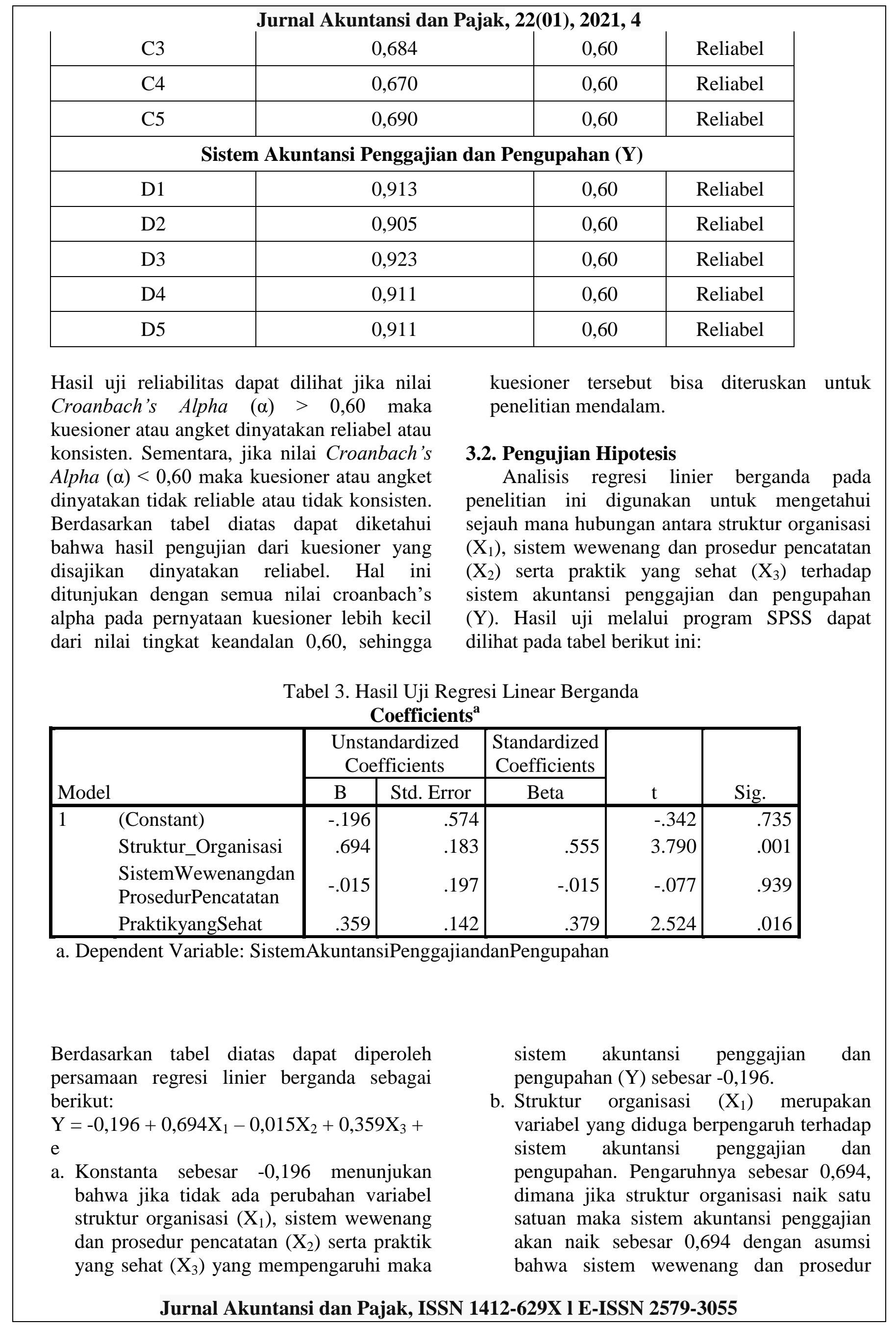


pencatatan $\left(\mathrm{X}_{2}\right)$ serta praktik yang sehat $\left(\mathrm{X}_{3}\right)$ bernilai konstant atau tetap.

c. Sistem wewenang dan prosedur pencatatan $\left(\mathrm{X}_{2}\right)$ merupakan variabel yang diduga berpengaruh terhadap sistem akuntansi penggajian dan pengupahan. Pengaruhnya sebesar -0,015, dimana jika sistem wewenang dan prosedur pencatatan naik satu satuan maka sistem akuntansi penggajian akan naik sebesar $-0,015$ dengan asumsi bahwa struktur organisasi $\left(\mathrm{X}_{1}\right)$ serta praktik yang sehat $\left(\mathrm{X}_{3}\right)$ bernilai konstant atau tetap.

d. Praktik yang sehat $\left(\mathrm{X}_{3}\right)$ merupakan variabel yang diduga berpengaruh terhadap sistem akuntansi penggajian dan pengupahan. Pengaruhnya sebesar 0,359, dimana jika praktik yang sehat naik satu satuan maka sistem akuntansi penggajian akan naik sebesar 0,359 dengan asumsi bahwa struktur organisasi $\left(\mathrm{X}_{1}\right)$ serta sistem wewenang dan prosedur pencatatan $\left(\mathrm{X}_{2}\right)$ bernilai konstant atau tetap.

\subsection{Hasil Penelitian}

Uji $\mathrm{F}$ dalam penelitian ini digunakan untuk mengetahui pengaruh struktur organisasi $\left(\mathrm{X}_{1}\right)$, sistem wewenang dan prosedur pencatatan $\left(\mathrm{X}_{2}\right)$ serta praktik yang sehat $\left(\mathrm{X}_{3}\right)$ secara bersamasama terhadap sistem akuntansi penggajian dan pengupahan (Y). Hasil uji $\mathrm{F}$ dapat dilihat pada tabel dibawah ini:

Tabel 4. Hasil Uji F (Simultan)

\begin{tabular}{|ll|r|r|r|r|c|}
\hline \multicolumn{7}{|c|}{ ANOVA $^{\mathrm{a}}$} \\
\hline & & Sum of Squares & df & Mean Square & F & Sig. \\
\hline & Regression & 6.630 & 3 & 2.210 & 22.446 & $.000^{\mathrm{b}}$ \\
& Residual & 3.446 & 35 & .098 & & \\
& Total & 10.076 & 38 & & & \\
\hline
\end{tabular}

a. Dependent Variable: SistemAkuntansiPenggajiandanPengupahan

b. Predictors: (Constant), PraktikyangSehat, Struktur_Organisasi,

SistemWewenangdanProsedurPencatatan

Berdasarkan tabel diatas dan sekaligus untuk menjawab perumusan masalah pada bab terdahulu, menunjukan bahwa tingkat signifikansi sebesar 0,000 , tingkat signifikansi tersebut lebih kecil dibandingkan dengan taraf 0,05 . Jika tingkat signifikansi $0,000<0,05$ maka hipotesis $\mathrm{Ha}_{4}$ diterima dan $\mathrm{HO}_{4}$ ditolak. Artinya terdapat pengaruh secara bersama-sama antara struktur organisasi, sistem wewenang dan prosedur pencatatan, praktik yang sehata terhadap sistem akuntansi penggajian dan pengupahan. Kriteria pengujian uji $\mathrm{F}$ pada penelitian ini juga menggunakan perbandingan antara $F_{\text {hitung }}$ dengan $F_{\text {tabel }}$. Berdasarkan tabel diatas diketahui bahwa $F_{\text {hitung }}$ sebesar 22,446. Dengan tingkat signifikansi $5 \%$ dan derajat kebebasan df 1 sebesar 3 dan df 2 sebesar 35 maka tabel $\mathrm{f}(3 ; 35)$ yaitu sebesar 2,87 (lihat lampiran $\left.F_{\text {tabel }}\right)$. Hal ini menunjukan bahwa $F_{\text {hitung }} 22,446$ lebih besar daripada $F_{\text {tabel }} 2,87$, maka hipotesis $\mathrm{H}_{4}$ diterima dan $\mathrm{H}_{0}$ ditolak yang artinya terdapat pengaruh secara bersama-sama antara struktur organisasi, sistem wewenang dan prosedur pencatatan, praktik yang sehata terhadap sistem akuntansi penggajian dan pengupahan.

Uji t digunakan dalam penelitian ini untuk mengetahui pengaruh struktur organisasi $\left(\mathrm{X}_{1}\right)$, sistem wewenang dan prosedur pencatatan $\left(\mathrm{X}_{2}\right)$ serta praktik yang sehat $\left(X_{3}\right)$ secara sendirisendiri (parsial) terhadap sistem akuntansi penggajian dan pengupahan $(\mathrm{Y})$. Penggunaan tingkat signifikansi pada penelitian ini, penulis menggunakan taraf 5\% (level of signifikan 0,05). Artinya jika nilai sig $<0,05$ maka hipotesis diterima (Ha) dan jika nilai sig > 0,05 maka hipotesis ditolak (H0). Penulis juga menggunakan kriteria pengujian dengan membandingkan antara nilai $t_{\text {hitung }}$ dan $t_{\text {tabel. }}$. Jika $t_{\text {hitung }}>t_{\text {tabel }}$ maka hipotesis diterima dan jika $t_{\text {hitung }}<t_{\text {tabel }}$ maka hipotesis ditolak. Hasil uji $t$ dapat dilihat pada tabel 4.9 hasil uji regresi linear berganda.

\section{KESIMPULAN}

a. Peranan unsur struktur organisasi berpengaruh terhadap sistem akuntansi 
penggajian dan pengupahan pada PT. Ardian Mulia Perkasa. Hal ini dibuktikan dengan hasil penelitian bahwa nilai signifikansi lebih kecil dari taraf $5 \%(0,000<0,05)$ dan nilai $t_{\text {hitung }}$ lebih besar daripada nilai $t_{\text {tabel }}$ $(3,790>2,022)$.

b. Peranan unsur sistem wewenang dan prosedur pencatatan tidak berpengaruh terhadap sistem akuntansi penggajian dan pengupahan pada PT. Ardian Mulia Perkasa. Hal ini dibuktikan dengan hasil penelitian bahwa nilai signifikansi lebih besar dari taraf $5 \%(0,939>0,05)$ dan nilai $t_{\text {hitung }}$ lebih kecil daripada nilai $\mathrm{t}_{\text {tabel }}(-0,077<2,022)$.

c. Peranan unsur praktik yang sehat berpengaruh terhadap sistem akuntansi penggajian dan pengupahan pada PT. Ardian Mulia Perkasa. Hal ini dibuktikan dengan hasil penelitian bahwa nilai signifikansi lebih kecil dari taraf $5 \%(0,016<0,05)$ dan nilai $\mathrm{t}_{\text {hitung }}$ lebih besar daripada nilai $\mathrm{t}_{\text {tabel }}$ $(2,524>2,022)$.

d. Peranan unsur struktur organisasi, sistem wewenang dan prosedur pencatatan, serta praktik yang sehat secara simultan berpengaruh terhadap sistem akuntansi penggajian dan pengupahan. Hal ini dibuktikan dengan hasil penelitian bahwa nilai signifikansi lebih kecil dari taraf 5\% $(0,000<0,05)$ dan nilai $F_{\text {hitung }}$ lebih besar daripada nilai $F_{\text {tabel }}(22,446>2,87)$ serta kontribusi pengaruh terhadap sistem akuntansi penggajian dan pengupahan sebesar $62,9 \%$ sedangkan sisanya sebesar $27,1 \%$ dipengaruhi oleh faktor lain yang tidak diteliti.

\section{REFERENSI}

Bahri, Syaiful. (2018). Metodologi Penelitian Bisnis Lengkap dengan Teknik Pengolahan Data SPSS. Yogyakarta : Penerbit Andi (Anggota IKAPI).

Kencono, Rio. (2016). Pengaruh Sistem Penggajian Terhadap Efektivitas Pengendalian Internal Gaji. Jurnal Ilmiah Revenue. Vol 2 No. 2 Juni 2016 (https://nanopdf.com/download/pengaruhsistem-penggajian-terhadap_pdf), diakses 02 Februari 2021
Lestari, Henny dkk. (2015). Analisis Pengaruh Sistem Pengendalian Internal Penggajian, Beban Kerja Dan Sarana Prasarana Terhadap Kepuasan Gaji Di SMA Negeri 42 Jakarta. Jurnal Ilmiah Ekonomi Bisnis. Vol 2 No. 2 Agustus 2015.(https://ejournal.gunadarma.ac.id/index .php/ekbis/article/view/1350), diakses 02 Februari 2021

Mulyadi. (2008). Auditing. Edisi 6. Jakarta : Salemba Empat.

Mulyadi. (2016). Sistem Akuntansi. Edisi 4. Jakarta : Salemba Empat.

Wardani, H. K. (2017). Akuntansi Dari Kacamata Syariah Dan Ekonomi Islam. Jurnal Ilmiah Ekonomi Islam, 3(03), 181-185.

Purnamasari, Andi Annisa. (2018). Pengaruh Sistem Informasi Akuntansi Penggajian Terhadap Efektivitas Pengendalian Internal Pembayaran Gaji Karyawan PT. Pos Indonesia (Persero) Pusat Kota Makassar. Skripsi. Makassar : Program Studi Akuntansi Universitas Negeri Makassar. (http://eprints.unm.ac.id/11947/) diakses tanggal 02 Februari 2021

Purwanty, Shanty. (2019). Pengaruh Sistem Informasi Dan Akuntansi Terhadap Pengendalian Internal Dan Dampaknya Terhadap Efektivitas Penggajian Di Kantor Pusat Universitas Pasundan. Jurnal Membangun Indonesia. Vol 19 No. 2MeiAgustus2019.

(https://jurnal.inaba.ac.id/index.php/JIM/arti cle/download/208/169) diakses 02 Februari 2021

Samanto, H \& Setyaningsih, N. (2020). Pengaruh Pengendalian Intern, Asimetri Informasi dan Kesesuaian Kompensasi Terhadap Kecenderungan Kecurangan Akuntansi. In Prosiding Seminar Nasional \& Call for Paper STIE AAS (pp. 043055).(http://prosiding.stieaas.ac.id/index.php/prosenas/article/view/46 ) diakses 01 April 2021

Septiani, Dwi. (2016). Pengaruh Sistem Pengendalian Intern Penggajian dan Sistem 
Jurnal Akuntansi dan Pajak, 22(01), 2021, 7

Informasi Akuntansi Penggajian Terhadap Penggajian. Skripsi. Banten :Program Studi Akuntansi Universitas Pamulang Banten. (http://openjournal.unpam.ac.id/index.php/JI A/article/download/182/116) diakses 02 Februari 2021

Sugiyono. (2010). Metode Penelitian Pendidikan Pendekatan Kuantitatif, Kualitatif dan $R \& D$. Bandung: Alfabeta.

Sugiarto. (2017). Metodologi Penelitian Bisnis. Yogyakarta : Penerbit Andi (Anggota IKAPI).

Sujarweni, V. Wiratna. (2020). Sistem Akuntansi. Yogyakarta : Pustaka Baru Press.
Sujarweni, V. Wiratna. (2020). Metodologi Penelitian Bisnis dan Ekonomi Pendekatan Kuantitatif . Yogyakarta : Pustaka Baru Press.

Sujarweni, V. Wiratna. (2020). Metodologi Penelian Bisnis dan Ekonomi. Yogyakarta : Pustaka Baru Press.

Syarkawi, (2019). Pengaruh Sistem Akuntansi Gaji Dan Upah Terhadap Efektivitas Pengendalian Internal Gaji Pada PT. SPBU Abad Jaya Di Kabupaten Bieureun. Skripsi. Aceh: Program Studi Akuntansi Universitas Muhammadiyah Aceh. (http://repository.unmuha.ac.id/xmlui/handle /123456789/524) diakses 02 Februari 2021 